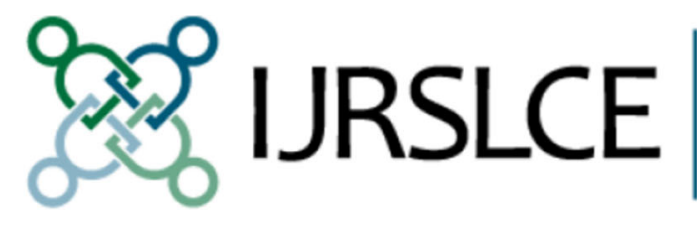

International Journal

for Research on

Service-Learning \&

Community Engagement

\title{
The Estimated Effects of Participation in Service-Learning on Liberal Arts Outcomes
}

\section{Cindy Ann Kilgo}

Kira Pasquesi, Jessica Kathryn Ezell Sheets, Ernest T. Pascarella

This article was originally published at:

https://journals.sfu.ca/iarslce/index.php/journal/article/view/78/21

Recommended Citation

Kilgo, C. A., Pasquesi, K., Sheets, J. K. E., \& Pascarella, E. T. (2014). The estimated effects of participation in service-learning on liberal arts outcomes. International Journal of Research on Service-Learning and Community Engagement, 2(1). 18-31. 


\title{
The Estimated Effects of Participation in Service-Learning on Liberal Arts Outcomes
}

\author{
Cindy Ann Kilgo \\ Kira Pasquesi \\ Jessica Kathryn Ezell Sheets \\ Ernest T. Pascarella \\ University of Iowa
}

\begin{abstract}
This study used data from a longitudinal, national study of recent college students to examine the estimated effects of students' participation in service-learning on six liberal arts outcomes. Findings indicate that service-learning was a positive, significant predictor for students' political and social involvement. Service-learning did not have a significant effect on students' growth regarding critical thinking, moral reasoning, inclination to inquire and lifelong learn, intercultural effectiveness, or psychological well-being.
\end{abstract}

Keywords: service-learning; liberal arts education

The higher education community has expressed mounting concern about students' overall attitudes toward community-mindedness, preparation for engaged citizenship, and levels of participation in civic life both during and after college (National Task Force on Civic Learning and Democratic Engagement, 2012). In response to this growing sense of misgiving, institutions of higher education have sought numerous ways to educate students for global citizenship. In addition to a variety of intra-institutional efforts, multiple coalitions have formed for the united purpose of committing - or recommitting - institutions of higher education to serving the public good. Campus Compact, the largest of these alliances, currently boasts nearly 1,200 institutional members, attesting to the widespread nature of the civic engagement movement (Campus Compact, 2013). Within this larger context, service-learning has garnered attention as a high-impact educational practice. With its connections to deep learning as well as civic outcomes, service-learning has been named a practice that promotes liberal arts educational outcomes among undergraduate students and promotes learning, engagement, and persistence (Brownell \& Swaner, 2010; Kuh, 2008). The Association of American Colleges and Universities (AAC\&U) has also recently named service-learning as a promising practice in educating students for personal and social responsibility (O'Neill, 2012).

Definitions of service-learning vary, but typically they all emphasize service-learning as a means for bridging classroom learning with participation in a community-based project (Bringle \& Clayton, 2012). Service-learning therefore differs from community service in that it integrates service with content knowledge attained in the classroom (see Astin, Oseguera, Sax, \& Korn, 2002; Kuh, 2008; Zlotkowski, 2002). While there is no consensus on a single definition of the term "service-learning," the current study operationally defines service-learning as participation in a community-based service project connected to a course. 


\section{Review of Literature}

Studies of community service and service-learning have explored the impact of the practices on students in relation to multiple liberal arts outcomes, including critical thinking, moral development, intercultural effectiveness, leadership skills, and civic responsibility and participation. While service participation has been linked to an increase in critical thinking skills (Astin \& Sax, 1998), servicelearning has been linked to growth in critical thinking above and beyond that suggested by service participation alone (Vogelgesang \& Astin, 2000).

In spite of service-learning's strong connection to civic learning, the results for the effects of service-learning on moral character have been mixed. Whereas Boss (1994) and Gorman, Duffy, and Heffernan (1994) found that students who participated in community service as part of their course requirements made greater gains in moral reasoning than those who did not, Bernacki and Jaegar (2008) did not find significant differences in moral reasoning among students taking servicelearning courses versus students taking analogous courses without a service component.

Service participation has been found to increase students' understanding of other cultures and their ability to get along with individuals from other cultures (Astin \& Sax, 1998), and numerous studies have found that participation in a service-learning course increases or enhances intercultural and diversity-related outcomes, including students' awareness of diversity (Simons \& Cleary, 2006), openness to new ideas, experiences, and people (Jones \& Abes, 2004), multicultural competence (Einfeld \& Collins, 2008), and global perspective-taking (Engberg \& Fox, 2011). On the other hand, Keen and Hall (2009) did not find that skills in dialogue across difference were enriched as a result of service-learning, and Kilgo (in press) found the effects of service-learning on intercultural effectiveness were mediated through good practices, such as academic challenge and positive interactions with diverse peers.

Some studies have also found that both service participation (Astin \& Sax, 1998) and servicelearning enhance leadership ability at comparable levels (Vogelgesang \& Astin, 2000). Finally, several studies have explored the linkages among service participation, service-learning, and students' sense of personal and social responsibility and civic involvement. These studies have found that service participation enhanced students' sense of civic responsibility (Astin \& Sax, 1998; Engberg \& Fox, 2011; Eyler \& Giles, 1999), led to students' emerging commitments to socially responsible work (Eyler \& Giles, 1999; Jones \& Abes, 2004), increased students' political awareness (Simons \& Cleary, 2006) and civic and community engagement (Keen \& Hall, 2009; Simons \& Cleary, 2006), and led to growth in students' feelings of civic and social responsibility (Brownell \& Swaner, 2010; Einfeld \& Collins, 2008; Pascarella \& Terenzini, 2005). Together, these studies provide initial evidence that participation in service-learning is positively associated with a variety of critical liberal arts learning outcomes among undergraduate students.

While the literature offers critical insight into a variety of outcomes related to service-learning, the studies conducted to date are limited in that they have generally included small sample sizes (e.g., Bernacki \& Jaeger, 2008; Boss, 1994; Gorman et al., 1994; Simons \& Cleary, 2006), lack generalizability (e.g., Einfeld \& Collins, 2008; Jones \& Abes, 2004; Keen \& Hall, 2009), relied on self-reported data (e.g., Vogelgesang \& Astin, 2000), did not include a pre- and post-test research design (Engberg \& Fox, 2011), and/or have focused on community service rather than servicelearning outcomes (e.g., Astin \& Sax, 1998). Further, few studies have examined the effects of service-learning on a wide range of educational outcomes. Given these limitations, there is a demonstrable need for a large-scale quantitative study on service-learning that explores a broad spectrum of liberal arts outcomes.

\section{Liberal Arts Conceptual Framework}

As indicated above, previous studies have linked service-learning to a breadth of significant educational outcomes across numerous dimensions. The current study seeks to build upon this line 
of inquiry, considering the liberal arts outcomes of service-learning through the lens of the comprehensive model of liberal arts educational outcomes developed by King, Kendall Brown, Lindsay, and VanHecke (2007). This model consists of seven liberal arts learning outcomes that together are argued to constitute a liberal arts education: (1) integration of learning, (2) inclination to inquire and lifelong learn, (3) effective reasoning and problem solving, (4) moral character, (5) intercultural effectiveness, (6) leadership, and (7) well-being. Together, the model suggests, these outcomes prepare "wise citizens" for an ever-changing world (King et al., 2007).

The purpose of this study is to examine the effects of students' participation in service-learning upon a variety of liberal arts outcomes. The current study explores the effects of service-learning on some of King et al.'s (2007) liberal arts learning outcomes plus another outcome-political and social involvement - that we feel directly links to the previous literature on service-learning. This study is significant because it employs a rigorous longitudinal research design to test the effects of service-learning on multiple liberal arts outcomes in a model that controls for numerous covariates; thus, it addresses a gap in the existing service-learning literature surrounding liberal arts outcomes. The study is guided by the following research question: What are the estimated effects of participation in service-learning on students' (1) critical thinking, (2) moral reasoning, (3) inclination to inquire and lifelong learn, (4) intercultural effectiveness, (5) psychological well-being, and (6) political and social involvement?

\section{Dependent Measures}

Dependent measures for the current study included six measures encompassing a variety of liberal arts educational outcomes: critical thinking, moral reasoning, inclination to inquire and lifelong learn, intercultural effectiveness, psychological well-being, and political and social involvement. The study included five of the seven outcome measures illustrated in the liberal arts theoretical framework of King et al. (2007). Further, given the recent emphasis on civic education by researchers, practitioners, and advocates of the liberal arts curriculum such as the AAC\&U, the study also included political and social involvement (PSI) as a measure of the civic outcomes emphasized in a liberal arts education (National Task Force, 2012).

\section{Critical Thinking}

Critical thinking was measured by the Collegiate Assessment of Academic Proficiency (CAAP), a 32-item scale measuring the ability of students to analyze, assess, and extend arguments. The CAAP was developed by the American College Testing Program. The CAAP has internal reliability consistencies ranging from 0.81 to 0.82 (ACT, 1991).

\section{Moral Reasoning}

Moral reasoning was measured by the N2 score of the Defining Issues Test-2 (DIT2), a 12-item scale measuring moral reasoning by evaluating students' responses to multiple social dilemmas. The DIT2 has internal consistency reliabilities ranging from 0.74 to 0.77 (Rest, Narvaez, Thoma, \& Bebeau, 1999).

\section{Inclination to Inquire and Lifelong Learn}

Inclination to inquire and lifelong learn was measured by the Need for Cognition Scale (NCS), a 19item scale measuring students' "tendency to engage in and enjoy effortful cognitive activity" (Cacioppo, Petty, Feinstein, \& Jarvis, 1996, p. 197). The NCS has internal consistency reliabilities ranging from 0.83 to 0.91 (Cacioppo et al., 1996). 


\section{Intercultural Effectiveness}

While the WNS includes two measures for intercultural effectiveness, the current study chose to examine only the Openness to Diversity/Challenge Scale (ODC) due to prior studies examining the effects of service-learning on the Miville-Guzman Universality-Diversity Scale (M-GUDS) (see Kilgo, in press). The ODC is a seven-item scale measuring students' enjoyment in interacting with diverse people and in considering diverse values and perspectives (Pascarella, Edison, Nora, Hagedorn, \& Terenzini, 1996). The ODC has internal consistency reliabilities ranging from 0.83 to 0.87 .

\section{Psychological Well-being}

Psychological well-being was measured by the total mean score of the Ryff Scales of Psychological Well-Being (RYFF), a 54-item scale measuring six areas: self-acceptance, personal growth, purpose in life, positive relations with others, environmental mastery, and autonomy (Keyes, Shmotkin, \& Ryff, 2002; Ryff, 1989; Ryff \& Keyes, 1995). The RYFF total mean scale has an internal consistency reliability of 0.92 .

\section{Political and Social Involvement}

The political and social involvement (PSI) scale is an 11-item scale measuring students' assigned level of importance for political and community involvement, such as volunteering, becoming a community leader, and affecting political structures. The PSI scale stems from items from the Cooperative Institutional Research Program (CIRP) Survey created by the Higher Education Research Institute (HERI) at the University of California at Los Angeles. The PSI has internal consistency reliabilities ranging from 0.80 to 0.83 .

\section{Independent Measures}

The study included several covariates based on the literature on service-learning. (All of the independent measures are described in more detail in the Appendix.) The study included a host of precollege control variables, including dichotomous variables for gender (male versus female), average parent education (parent education averaged a bachelor's degree or higher versus parent education did not average a bachelor's degree or higher), high school political views (far left/liberal versus middle of the road/conservative/far right), high school volunteer involvement (occasionally/often/very often versus never/rarely), and paid employment during high school (occasionally/often/very often versus never/rarely). Due to small sample sizes within individual race categories, the current study was not able to disaggregate individual race categories. Therefore, one dichotomous variable controlling for race was included (students of color versus white). Continuous measures were included for precollege academic motivation and precollege academic ability (ACT composite score). Further, the pretest measures for all six dependent variables of the study were included to control for students' precollege levels.

Two dichotomous variables were included to control for institutional characteristics (regional university and research university, with liberal arts colleges serving as the omitted category for both). Several college experience control variables were included, such as dichotomous variables for fraternity or sorority affiliation (member of a fraternity/sorority versus not a member) and academic major (social sciences/humanities major versus other majors), and a continuous measure for working on and off campus for pay. The current study also incorporated six vetted good practices variablessuggested to provide positive benefits for students' personal growth and development (see Chickering \& Gamson, 1987; Chickering \& Reisser, 1993; Pascarella \& Terenzini, 2005)— including: faculty interest in teaching/student development $(\alpha=0.87)$, diversity experiences $(\alpha=$ $0.69)$, integrative learning $(\alpha=0.77)$, positive interactions with diverse peers $(\alpha=0.83)$, academic challenge $(\alpha=0.66)$, and cooperative learning $(\alpha=0.68)$. Finally, the independent variable of 
interest in the current study was a dichotomous variable for service-learning participation at the end of the fourth year (did participate versus did not participate).

\section{Analyses}

All continuous dependent and independent measures were standardized. After listwise deletion was conducted, the following sample sizes remained: CAAP $(n=886)$, DIT2 $(n=910)$, NCS $(n=1,852)$, ODC $(n=1,856)$, RYFF $(n=1,841)$, and PSI $(n=1,857)$. For each dependent measure within the current study, series of ordinary least squares regressions (OLS) were conducted separately. Due to the inability to account for the nested nature of the study $(N-1)$, conservative $p$-values $(p<0.025, p$ $<0.01$, and $p<0.001$ ) were used. A correlation matrix to check for multicollinearity was computed for all independent variables and is represented in Table 1.

As illustrated in Table 1, most of the correlations are small. The three largest correlations among independent variables all occurred within the good practices variables, with: faculty interest in student development/teaching and integrative learning $(r=0.38)$, integrative learning and academic challenge $(r=0.48)$, and diversity experiences and positive interactions with diverse peers $(r=0.65)$. Further, variance inflation factors (VIF) were also calculated for each regression model to check for multicollinearity. Five of the six models (DIT2, NCS, ODC, RYFF, and PSI) had VIFs below the conservative level of 2.5 (see Allison, 1999). The VIFs for the CAAP model was 2.59 but was well below the less conservative threshold of 10.0 (see Stevens, 2002).

Descriptive analyses were conducted to examine the sample. Table 2 displays the descriptives for the current study. The overall sample was largely White and female; 18 percent reported identifying as students of color, and 36 percent reported identifying as male. The mean ACT Composite Score for the sample was 27.29. Of the six dependent measures in the study, the mean score for the sample was higher at time three (as opposed to time one which was the precollege control within the study) for four measures: critical thinking, moral reasoning, need for cognition, and psychological well-being. For two of the six dependent measures-intercultural effectiveness and political and social involvement - the precollege mean was higher than the post-test (time three) mean for the overall sample. Finally, over half the sample (53\%) reported participating in servicelearning at some point over the four years of college.

\section{Results}

The direct effects from the current study's models are presented in Table 3. The findings suggest that, while controlling for a host of precollege and college experience variables, service-learning was a significant, positive predictor for students' political and social involvement $(B=0.1002, p<0.01)$. Essentially, students who participated in service-learning scored higher on the PSI scale, which measures students' self-ratings of the importance of activities such as volunteering, political involvement, and voting, among others.

Service-learning was not a significant predictor for any of the other outcome measures, including critical thinking, moral reasoning, inclination to inquire and lifelong learn, intercultural effectiveness, or psychological well-being. An important limitation of the current study, however, is the coding of the independent variable of interest - service-learning. The item included in our analysis from WNS asked students how often they "participated in a community-based project (e.g., service-learning) as part of a regular course," and the variable was dichotomized (participation versus not). Due to the nature of the item, we are unable to make distinctions between the various types of service-learning experiences and what, if any, differing effects they might have on students' growth in relation to liberal arts outcomes. If the study had controlled for the type of servicelearning experience, the findings might have been more consistent with the literature, suggesting positive benefits to students. 
Table 1. Correlation Matrix among Independent Variables

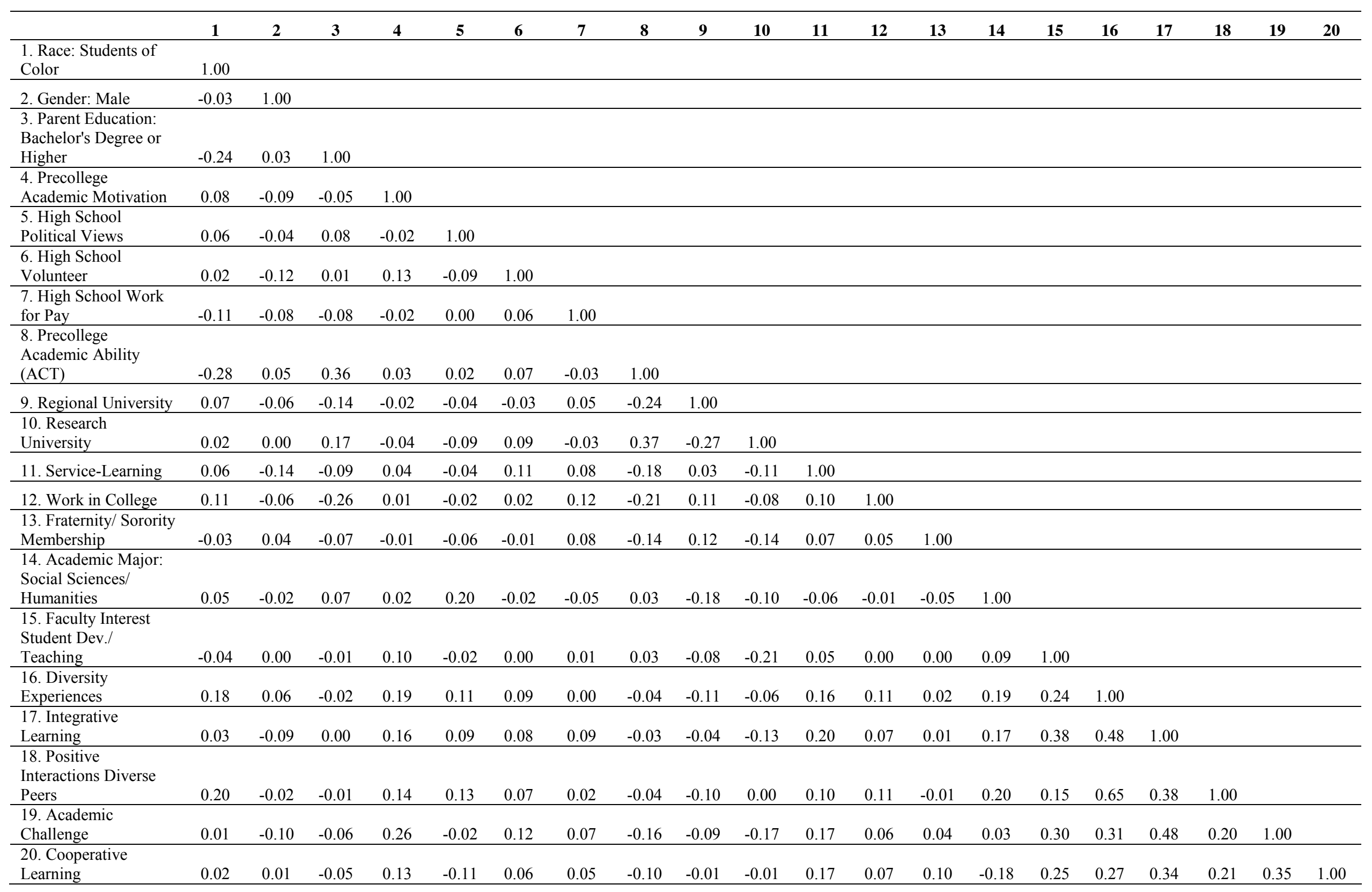


Table 2 . Descriptive Statistics on Precollege and College Experience Variables by Participation in Service-Learning using the Wabash National Study of Liberal Arts Education

\begin{tabular}{|c|c|c|c|c|c|c|c|c|c|c|c|c|}
\hline \multirow[b]{2}{*}{ Variables } & \multicolumn{6}{|c|}{ Participation in Service-Learning } & \multicolumn{6}{|c|}{ No Participation in Service-Learning } \\
\hline & Mean & SD & Freq. & $\%$ & Min. & Max. & Mean & SD & Freq. & $\%$ & Min. & Max. \\
\hline Senior-Year Level of Critical Thinking & 64.61 & 6.37 & & & 49 & 73 & 66.82 & 4.84 & & & 49 & 73 \\
\hline Precollege Level of Critical Thinking & 62.38 & 5.32 & & & 47 & 73 & 64.72 & 5.24 & & & 48 & 73 \\
\hline Senior-Year Level of Moral Reasoning & 43.69 & 14.63 & & & -1.09 & 77.98 & 46.57 & 14.87 & & & -2.19 & 83.83 \\
\hline Precollege Level of Moral Reasoning & 35.66 & 15.04 & & & -8.84 & 74.71 & 38.64 & 15.37 & & & -8.84 & 81.22 \\
\hline Senior-Year Level of Need for Cognition & 3.68 & 0.59 & & & 1.17 & 5 & 3.71 & 0.59 & & & 1.17 & 5 \\
\hline Precollege Level of Need for Cognition & 3.48 & 0.59 & & & 1.22 & 5 & 3.68 & 0.59 & & & 1.17 & 5 \\
\hline Senior-Year Level of Openness to Diversity/Challenge & 3.92 & 0.67 & & & 1.29 & 5 & 3.79 & 0.58 & & & 1 & 5 \\
\hline Precollege Level of Openness to Diversity/Challenge & 3.96 & 0.59 & & & 1 & 5 & 3.91 & 0.63 & & & 1 & 5 \\
\hline Senior-Year Level of RYFF & 4.77 & 0.57 & & & 2.46 & 6 & 4.66 & 0.59 & & & 1.94 & 5.98 \\
\hline Precollege Level of RYFF & 4.59 & 0.57 & & & 2.29 & 5.92 & 4.52 & 0.56 & & & 2.38 & 5.94 \\
\hline Senior-Year Level of Political and Social Involvement & 2.74 & 0.57 & & & 1 & 4 & 2.46 & 0.57 & & & 1 & 4 \\
\hline Precollege Level of Political and Social Involvement & 2.75 & 0.49 & & & 1.18 & 4 & 2.61 & 0.51 & & & 1 & 4 \\
\hline \multicolumn{13}{|l|}{ Covariates } \\
\hline Students of Color & & & 449 & 24.14 & 0 & 1 & & & 262 & 18.11 & 0 & 1 \\
\hline Male & & & 602 & 31.89 & 0 & 1 & & & 646 & 44.16 & 0 & 1 \\
\hline Average Parent Education & 15.44 & 2.20 & & & 11 & 20 & 15.85 & 2.12 & & & 11 & 20 \\
\hline Precollege Academic Motivation & 3.64 & 0.53 & & & 1.5 & 5 & 3.59 & 0.56 & & & 1.75 & 5 \\
\hline Precollege Political Views (Liberal) & & & 713 & 38.27 & 0 & 1 & & & 623 & 43.05 & 0 & 1 \\
\hline High School Volunteer Work & & & 1482 & 81.92 & 0 & 1 & & & 1023 & 71.14 & 0 & 1 \\
\hline High School Work for Pay & & & 1212 & 66.92 & 0 & 1 & & & 836 & 58.1 & 0 & 1 \\
\hline ACT Composite Score & 25.88 & 4.58 & & & 10 & 36 & 27.85 & 4.26 & & & 13 & 36 \\
\hline Research University & & & 379 & 20.07 & 0 & 1 & & & 363 & 24.81 & 0 & 1 \\
\hline Regional University & & & 414 & 21.93 & 0 & 1 & & & 254 & 17.36 & 0 & 1 \\
\hline Work Per Week in College & 9.64 & 8.98 & & & 0 & 65 & 7.88 & 8.15 & & & 0 & 50 \\
\hline Fraternity/Sorority Affiliation & & & 406 & 21.53 & 0 & 1 & & & 249 & 17.04 & 0 & 1 \\
\hline Social Sciences/Humanities Major & & & 795 & 44.59 & 0 & 1 & & & 688 & 50.22 & 0 & 1 \\
\hline Faculty Interest in Student Development & 0.03 & 0.82 & & & -4.04 & 1.09 & -0.04 & 0.79 & & & -4.04 & 1.09 \\
\hline Diversity Experiences & 0.09 & 0.63 & & & -1.50 & 2.04 & -0.14 & 0.58 & & & -1.50 & 1.92 \\
\hline Integrative Learning & 0.10 & 0.54 & & & -2.07 & 1.10 & -0.14 & 0.62 & & & -2.22 & 1.10 \\
\hline Positive Interactions with Diverse Peers & 0.07 & 0.85 & & & -1.83 & 1.79 & -0.13 & 0.85 & & & -1.83 & 1.74 \\
\hline Academic Challenge and Effort & 0.08 & 0.46 & & & -1.62 & 1.63 & -0.10 & 0.47 & & & -1.78 & 1.32 \\
\hline Cooperative Learning & 0.13 & 0.69 & & & -1.97 & 1.52 & -0.15 & 0.71 & & & -1.97 & 1.52 \\
\hline
\end{tabular}


Table 3. Estimated Effects of Participation in Service-Learning on Liberal Arts Outcomes

\begin{tabular}{|c|c|c|c|c|c|c|}
\hline & 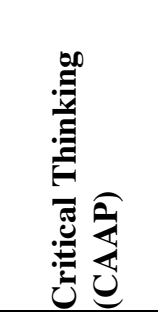 & 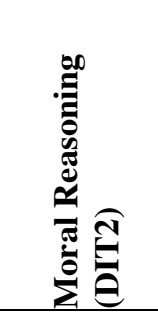 & 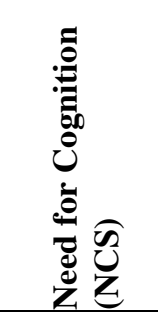 & 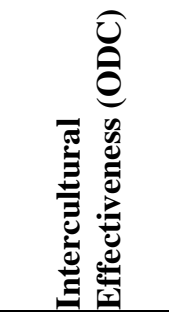 & 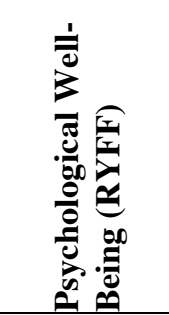 & 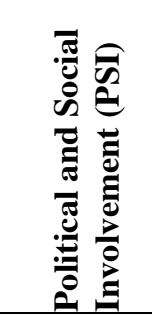 \\
\hline & $\mathrm{n}=886$ & $\mathrm{n}=910$ & $\mathrm{n}=1852$ & $\mathrm{n}=1856$ & $\mathrm{n}=1841$ & $\mathrm{n}=1857$ \\
\hline & $\beta$ & $\beta$ & $\beta$ & $\beta$ & $\beta$ & $\beta$ \\
\hline \multicolumn{7}{|l|}{ Precollege Variables } \\
\hline Race - Students of Color & 0.0632 & $-0.2221 * *$ & $-0.1601 * * *$ & $0.1441^{* *}$ & -0.0909 & 0.0755 \\
\hline Gender - Male & 0.0603 & $-0.1356^{*}$ & $0.1846 * * *$ & -0.0789 & -0.0630 & -0.0604 \\
\hline $\begin{array}{l}\text { Parent Education Average } \\
\text { Precollege Academic }\end{array}$ & -0.0038 & -0.0047 & 0.0041 & $-0.0593 * * *$ & 0.0097 & $0.0668 * * *$ \\
\hline Motivation & -0.0447 & -0.0237 & -0.0258 & $-0.0625 * * *$ & $-0.1660 * * *$ & $-0.0739 * * *$ \\
\hline High School Political Views & 0.0126 & 0.0103 & 0.0546 & -0.0729 & $-0.0961^{*}$ & -0.0693 \\
\hline High School Volunteer & 0.0417 & 0.0487 & -0.0835 & -0.0532 & 0.0389 & 0.0207 \\
\hline $\begin{array}{l}\text { High School Work for Pay } \\
\text { Precollege Academic Ability } \\
\text { (ACT) }\end{array}$ & $0.3025^{* * *}$ & $0.1213 * * *$ & $0.1692 * * *$ & -0.0656 & -0.0197 & $\begin{array}{l}0.0667 \\
-0.0043\end{array}$ \\
\hline Pretest & $0.5187 * * *$ & $0.5199 * * *$ & $0.4646^{* * *}$ & $0.3805 * * *$ & $0.5028^{* * *}$ & $0.4043 * * *$ \\
\hline $\begin{array}{l}\text { Institutional Type Variables } \\
\text { Institutional Type - Regional } \\
\text { University } \\
\text { Institutional Type - Research }\end{array}$ & -0.0551 & 0.0162 & 0.0716 & 0.0474 & $-0.0002 *$ & 0.0158 \\
\hline $\begin{array}{l}\text { University } \\
\text { College Experience Variables }\end{array}$ & 0.0769 & 0.0493 & -0.0456 & 0.0794 & 0.1143 & 0.0389 \\
\hline Service-Learning & -0.0347 & 0.0066 & -0.0528 & -0.0687 & -0.0013 & $0.1002 * *$ \\
\hline Work in College & 0.0351 & -0.0128 & 0.0145 & $-0.0417 *$ & 0.0255 & 0.0381 \\
\hline $\begin{array}{l}\text { Fraternity/Sorority Affiliation } \\
\text { Major - Social }\end{array}$ & $-0.1725 * *$ & 0.1167 & 0.0763 & $-0.0031 * * *$ & $0.1133 *$ & -0.0478 \\
\hline $\begin{array}{l}\text { Sciences/Humanities } \\
\text { Faculty Interest in }\end{array}$ & -0.0673 & 0.0407 & -0.0001 & 0.1469 & $-0.1031 *$ & 0.0141 \\
\hline Teaching/Student Development & 0.0274 & 0.0316 & 0.0391 & 0.0332 & $0.1102 * * *$ & 0.0216 \\
\hline Diversity Experiences & 0.0646 & -0.0742 & $0.0917 * * *$ & $0.2155^{* * *}$ & $0.0675^{*}$ & $0.1869^{* * *}$ \\
\hline $\begin{array}{l}\text { Integrative Learning } \\
\text { Positive Interactions with }\end{array}$ & 0.0179 & $0.1072 * *$ & $0.1763 * * *$ & $0.1611^{* * *}$ & $0.1238 * * *$ & $0.2128 * * *$ \\
\hline Diverse Peers & -0.0215 & 0.0494 & 0.0036 & $0.2005^{* * *}$ & 0.0209 & $0.1163 * * *$ \\
\hline Academic Challenge & 0.0099 & -0.0023 & 0.1342 & 0.0317 & $0.1672 * * *$ & 0.0441 \\
\hline Cooperative Learning & 0.0014 & -0.0139 & -0.0181 & 0.0114 & 0.0001 & $-0.0482 *$ \\
\hline $\mathrm{R}^{2}$ & 0.62 & 0.42 & 0.46 & 0.49 & 0.42 & 0.45 \\
\hline
\end{tabular}

Note: $p<0.025^{*}, p<0.01 * *, p<0.001$ 


\section{Discussion}

The current study examined the effects of students' participation in service-learning on a variety of measures comprising six liberal arts outcomes. The study utilized a comprehensive model of liberal arts outcomes (King et al., 2007) to build upon a small body of research focusing on the integration of liberal arts outcomes on particular student experiences (see Martin et al., 2011). The analyses compared students who participated in a course-based service-learning experience to those who did not. Given the longitudinal nature of the WNS, the study applied statistical controls for potentially confounding variables, such as family background, high school experiences, and college experiences, as well as controlling for precollege levels for each outcome via pre-tests. The results indicated that service-learning was a positive, significant predictor for students' political and social involvement. Findings also indicated that service-learning did not have a significant effect on students' growth along other key liberal arts outcomes, including critical thinking, moral reasoning, inclination to inquire and lifelong learn, intercultural effectiveness, and psychological well-being.

This study's finding that service-learning was a significant, positive predictor of students' political and social involvement supports a long line of research on the positive effects of servicelearning for civic responsibility and participation (e.g., Brownell \& Swaner, 2010; Einfeld \& Collins, 2008; Engberg \& Fox, 2011; Eyler \& Giles, 1999; Jones \& Abes, 2004; Simons \& Cleary, 2006). As noted by the National Task Force on Civic Learning and Democratic Engagement (2012), servicelearning is a "dominant curricular vehicle for promoting different dimensions of civic learning and engaging with larger communities" (p. 58). Institutions of higher education continue to expand service-learning course offerings (National Task Force, 2012) and have begun to construct academic programs, such as certificates, minors, and majors, focusing on community engagement (Butin \& Seider, 2012). The study's findings provide additional evidence that these types of service-learning initiatives could potentially increase students' political and social involvement.

It is important to note that the results indicate that service-learning predicts less of a decrease in students' political and social involvement than students who did not participate in service-learning. In other words, all students were slightly less politically and socially involved after four years of college, but students participating in service-learning had smaller decreases in involvement than those who did not participate in service-learning. This suggests that service-learning may buffer the decrease over four years of college. The finding warrants further study in order to assess why students experience an overall decrease in political and social involvement during college and what practices may attenuate this concerning finding.

The study's surprising findings that participation in service-learning did not significantly affect students' levels of critical thinking, moral reasoning, inclination to inquire and lifelong learn, intercultural effectiveness, and psychological well-being raises questions about service-learning as an approach to further liberal arts outcomes. Service-learning has been promoted as a promising educational practice to enhance students' liberal learning (Kuh, Kinzie, Schuh, Whitt, \& Associates, 2010). As such, colleges and universities across the country are allocating substantial financial resources and staff time to supporting service-learning efforts on their campuses. Institutions hire staff devoted to service-learning course development, faculty training in engaged teaching strategies, and building and maintaining community partnerships coordinated out of centers or institutions designed to encourage democratic engagement. The findings from this study emphasize the need for empirical evidence of the effects of service-learning as colleges and universities continue to look to service-learning as a promising educational practice that promotes gains in liberal arts learning outcomes.

Given both the findings and limitations of this study, future research should control for the types of service-learning experiences and the ways in which the experiences are facilitated. Educators make pedagogical choices in service-learning experiences surrounding course content, decisionmaking, and relationships with community partners that have implications for student growth across 
liberal arts outcomes. As the National Task Force on Civic Learning and Democratic Engagement (2012) asserts, it is imperative for practitioners to consider the "nuances between kinds of service experience, levels of student responsibility, scale of issues addressed, learning outcomes sought, and the impact of engagement on community partners" (p. 60). Future research could also be conducted on an institutional level to explore the degree of alignment between institutional priorities and educational outcomes stemming from participation in service-learning experiences.

This longitudinal study employed rigorous statistical controls and a pre-test to examine the effects of participation in service-learning on an array of liberal arts outcomes. It is important for future research on the effects of service-learning to take into account potentially confounding variables and account for institutional and college experience controls when exploring various facets of service-learning participation. For example, future studies could examine whether good practices - such as academic challenge, integrative learning, diversity experiences, etc.-mediate the effects of participation in service-learning on students' growth across various measures of liberal arts outcomes. Future researchers could also consider the conditional effects of participation in servicelearning for various subpopulations according to race, gender, and academic ability.

As institutions of higher education continue to invest in civically-oriented practices, such as service-learning, it is increasingly important to examine the effects of such initiatives across a wide range of outcomes. This study provides additional evidence to support service-learning's potential to educate students for responsible citizenship while also calling into question the effect of servicelearning on other key liberal arts outcomes. Researchers should continue to conduct rigorous studies to empirically investigate liberal arts learning outcomes in relation to students' service-learning experiences to better understand service-learning as a component of liberal arts education. 


\section{Appendix}

\section{Descriptions of Independent Variables/Measures Included in Study}

\begin{tabular}{|c|c|c|}
\hline Variable & Survey Question/(Options) & Coded Values \\
\hline $\begin{array}{l}\text { Race - Students of } \\
\text { Color }\end{array}$ & $\begin{array}{l}\text { "What is your race/ethnicity?" } \\
\text { (Nonresident alien, Black, non-Hispanic, American } \\
\text { Indian/Alaska Native, Asian/Pacific Islander, } \\
\text { Hispanic, White, non-Hispanic, Race/ethnicity } \\
\text { unknown, Multiple/invalid/indecipherable } \\
\text { response) }\end{array}$ & $\begin{array}{l}{[1=\text { Students of Color }]} \\
{[0=\text { White students }]} \\
\text { (Note: Nonresident alien, } \\
\text { Race/ethnicity unknown, } \\
\text { Multiple/invalid/indecipherable } \\
\text { response dropped.) }\end{array}$ \\
\hline Gender - Male & $\begin{array}{l}\text { "What is your gender?" } \\
\text { (Male, Female, Multiple/invalid/indecipherable } \\
\text { response) }\end{array}$ & $\begin{array}{l}{[1=\text { Male }]} \\
{[0=\text { Female }]} \\
\text { (Note: } \\
\text { Multiple/invalid/indecipherable } \\
\text { response dropped.) }\end{array}$ \\
\hline $\begin{array}{l}\text { Parent Education } \\
\text { Average }\end{array}$ & $\begin{array}{l}\text { "What is the highest level of education each of your } \\
\text { parents/guardians completed?" } \\
\text { (Did not finish high school, High school } \\
\text { graduate/GED, Attended college but no degree, } \\
\text { Vocational/technical certificate or diploma, } \\
\text { Associate or other 2-year degree, Bachelors or } \\
\text { other 4-year degree, Masters, Law, Doctorate) }\end{array}$ & $\begin{array}{l}\text { Mean of education for both } \\
\text { mother and father }\end{array}$ \\
\hline $\begin{array}{l}\text { Precollege Academic } \\
\text { Motivation }\end{array}$ & $\begin{array}{l}\text { Measure consisted of eight-items. Sample items } \\
\text { include: "I am willing to work hard in a course to } \\
\text { learn the material even if it won't lead to a higher } \\
\text { grade" and "In high school, I frequently did more } \\
\text { reading in a class than was required simply because } \\
\text { it interested me." }\end{array}$ & $\begin{array}{l}\text { Continuous measure, } \\
\text { standardized }\end{array}$ \\
\hline $\begin{array}{l}\text { High School Political } \\
\text { Views }\end{array}$ & $\begin{array}{l}\text { How would you characterize your political views? } \\
\text { (Far left, Liberal, Middle-of-the-road, } \\
\text { Conservative, Far Right) }\end{array}$ & $\begin{array}{l}{[1=\text { Far Left/Liberal }]} \\
{[0=\text { Middle of }} \\
\text { Road/Conservative/Far Right }]\end{array}$ \\
\hline $\begin{array}{l}\text { High School } \\
\text { Volunteer }\end{array}$ & $\begin{array}{l}\text { "During your last year in high school, how often } \\
\text { did you engage in each of the following activities?" } \\
\text { (Very Often, Often, Occasionally, Rarely, Never) }\end{array}$ & $\begin{array}{l}{[1=\text { Occasionally, Often, Very }} \\
\text { Often }] \\
{[0=\text { Never, Rarely }]}\end{array}$ \\
\hline $\begin{array}{l}\text { High School Work for } \\
\text { Pay }\end{array}$ & $\begin{array}{l}\text { "During your last year in high school, how often } \\
\text { did you engage in each of the following activities?" } \\
\text { (Very Often, Often, Occasionally, Rarely, Never) }\end{array}$ & $\begin{array}{l}{[1=\text { Occasionally, Often, Very }} \\
\text { Often }] \\
{[0=\text { Never, Rarely }]}\end{array}$ \\
\hline $\begin{array}{l}\text { Precollege Academic } \\
\text { Ability (ACT) }\end{array}$ & ACT Composite Score or SAT equivalent & Continuous, standardized. \\
\hline $\begin{array}{l}\text { Institutional Type - } \\
\text { Regional University }\end{array}$ & & $\begin{array}{l}{[1=\text { Regional University }]} \\
{[0=\text { Liberal Arts College }]}\end{array}$ \\
\hline $\begin{array}{l}\text { Institutional Type - } \\
\text { Research University }\end{array}$ & & $\begin{array}{l}{[1=\text { Research University }]} \\
{[0=\text { Liberal Arts College }]}\end{array}$ \\
\hline Service-Learning & $\begin{array}{l}\text { "In your experience at your institution during the } \\
\text { current school year, about how often have you } \\
\text { participated in a community-based project (e.g., } \\
\text { service learning) as part of a regular course" } \\
\text { (Never, Sometimes, Often, Very often) }\end{array}$ & $\begin{array}{l}{[1=\text { Sometimes, Often, Very }} \\
\text { Often }] \\
{[0=\text { Never }]}\end{array}$ \\
\hline Work in College & $\begin{array}{l}\text { "About how many hours in a typical week do you } \\
\text { spend doing the following: Working for pay on } \\
\text { campus, Working for pay off campus" }\end{array}$ & $\begin{array}{l}\text { Combined mean of two } \\
\text { variables, continuous, } \\
\text { standardized. }\end{array}$ \\
\hline $\begin{array}{l}\text { Fraternity/Sorority } \\
\text { Affiliation }\end{array}$ & $\begin{array}{l}\text { "Are you a member of a social fraternity or } \\
\text { sorority?" } \\
\text { (Yes, No) }\end{array}$ & $\begin{array}{l}{[1=\mathrm{Yes}]} \\
{[0=\mathrm{No}]}\end{array}$ \\
\hline
\end{tabular}




\begin{tabular}{|c|c|c|}
\hline Variable & Survey Question/(Options) & Coded Values \\
\hline $\begin{array}{l}\text { Major - Social } \\
\text { Sciences/Humanities }\end{array}$ & $\begin{array}{l}\text { "Please print your primary major or your expected } \\
\text { primary major." }\end{array}$ & $\begin{array}{l}{[1=\text { Social }} \\
\text { Sciences/Humanities }] \\
{[0=\text { Else }]}\end{array}$ \\
\hline $\begin{array}{l}\text { Faculty Interest in } \\
\text { Teaching/Student } \\
\text { Development }\end{array}$ & $\begin{array}{l}\text { Measure consisted of five-items. Sample items } \\
\text { include: "Most faculty with whom R had contact } \\
\text { are genuinely interested in students" and "Most } \\
\text { faculty with whom R had contact are genuinely } \\
\text { interested in teaching." }\end{array}$ & Continuous, standardized. \\
\hline Diversity Experiences & $\begin{array}{l}\text { Measure consisted of six-items. Sample items } \\
\text { include: "How often R attended a debate or lecture } \\
\text { on a current political/social issue during this } \\
\text { academic year," "Extent to which R's institution } \\
\text { emphasizes encouraging contact among students } \\
\text { from different economic, social, and racial or ethnic } \\
\text { backgrounds," and "How often R participated in a } \\
\text { racial or cultural awareness workshop during this } \\
\text { academic year." }\end{array}$ & Continuous, standardized. \\
\hline Integrative Learning & $\begin{array}{l}\text { Measure consisted of nine-items. Sample items } \\
\text { include: "The extent R agrees that courses have } \\
\text { helped R see the connections between intended } \\
\text { career and how it affects society" and "During } \\
\text { current school year, how often has R worked on a } \\
\text { paper or project that required integrating ideas or } \\
\text { information from various sources." }\end{array}$ & Continuous, standardized. \\
\hline $\begin{array}{l}\text { Positive Interactions } \\
\text { with Diverse Peers }\end{array}$ & $\begin{array}{l}\text { Measure consisted of eight-items. Sample items } \\
\text { include: "Interpersonal relationships with other } \\
\text { students have had a positive influence on Rs } \\
\text { intellectual growth and interest in ideas," and "Few } \\
\text { of the students R knows would be willing to listen } \\
\text { to and help R with a personal problem (reverse- } \\
\text { coded)." }\end{array}$ & Continuous, standardized. \\
\hline Academic Challenge & $\begin{array}{l}\text { Measure consisted of 11-items. Sample items } \\
\text { include: "Number of hours per week R spends } \\
\text { preparing for class," "In a typical week, the number } \\
\text { of problem sets that takes R more than an hour to } \\
\text { complete," and "Extent to which R's institution } \\
\text { emphasizes spending significant amounts of time } \\
\text { studying and on academic work." }\end{array}$ & Continuous, standardized. \\
\hline Cooperative Learning & $\begin{array}{l}\text { Measure consisted of four-items. Sample items } \\
\text { include: "In Rs classes, students taught each other } \\
\text { in addition to faculty teaching" and "R participated } \\
\text { in one or more study group(s) outside of class." }\end{array}$ & Continuous, standardized. \\
\hline
\end{tabular}

Note: Pre-test measures for all dependent variables detailed within text of article. 
30 | International Journal of Research on Service-Learning and Community Engagement

\section{Correspondence}

Correspondence concerning this article should be addressed to: Cindy Ann Kilgo, Doctoral Student, Higher Education and Student Affairs, College of Education, University of Iowa; cindykilgo@uiowa.edu

\section{References}

Allison, P. D. (1999). Logistic regression using the SAS system: Theory and application. Cary, NC: SAS Press.

American College Testing Program. (1991). CAAP technical handbook. Iowa City, IA: ACT.

Astin, A. W., \& Sax, L. J. (1998). How undergraduates are affected by service participation. Journal of College Student Development, 39(3), 251-263.

Astin, A. W., Oseguera, L., Sax, L. J., \& Korn, W. S. (2002). The American freshman: Thirty-five year trends. Los Angeles, CA: Higher Education Research Institute, UCLA.

Bernacki, M. L., \& Jaegar, E. (2008). Exploring the impact of service-learning on moral development and moral orientation. Michigan Journal of Community Service Learning, 14(2), 5 15 .

Boss, J. A. (1994). The effect of community service work on the moral development of college ethics students. Journal of Moral Education, 23(2), 183-198.

Bringle, R. G. \& Clayton, P. H. (2012). Civic education through service learning: What, how, and why? In L. McIlrath, A. Lyons, \& R. Munck (Eds.), Higher education and civic engagement: Comparative perspectives (pp. 101-123). New York, NY: Palgrave Macmillian.

Brownell, J. E., \& Swaner, L. E. (2010). Five high-impact practices: Research on learning outcomes, completion and quality. Washington, DC: Association of American Colleges and Universities.

Butin, D. W., \& Seider, S. (Eds.). (2012). The engaged campus: Certificates, minors, and majors as the new community engagement. New York, NY: Palgrave Macmillan.

Cacioppo, J., Petty, R., Feinstein, J., \& Jarvis, W. (1996). Dispositional differences in cognitive motivation: The life and times of individuals varying in need for cognition. Psychological Bulletin, 119, 197-253.

Campus Compact. (2013). Who we are. Retrieved from http://www.compact.org/about/historymission-vision/

Chickering, A. W., \& Gamson, Z. F. (1987). Seven principles for good practice in undergraduate education. AAHE Bulletin, 39(7), 3-7.

Chickering, A. W., \& Reisser, L. (1993). Education and identity (2nd ed.). San Francisco, CA: Jossey-Bass.

Einfeld, A., \& Collins, D. (2008). The relationships between service-learning, social justice, multicultural competence, and civic engagement. Journal of College Student Development, 49(2), 95-109.

Engberg, M. E., \& Fox, K. (2011). Exploring the relationship between undergraduate servicelearning experiences and global perspective-taking. Journal of Student Affairs Research and Practice, 48(1), 85-105.

Eyler, J., \& Giles, D. E., Jr. (1999). Where's the learning in service-learning? San Francisco, CA: Jossey-Bass.

Gorman, M., Duffy, J., \& Heffernan, M. (1994). Service experience and the moral development of college students. Religious Education, 89(3), 422-431.

Jones, S. R., \& Abes, E. S. (2004). Enduring influences of service-learning on college students' identity development. Journal of College Student Development, 45(2), 149-166.

Keen, C., \& Hall, K. (2009). Engaging with difference matters: Longitudinal student outcomes of cocurricular service-learning programs. The Journal of Higher Education, 80(1), 59-79. 
Keyes, C., Shmotkin, D., \& Ryff, C. (2002). Optimizing well-being: The empirical encounter of two traditions. Journal of Personality and Social Psychology, 82, 1007-1022.

Kilgo, C. A. (in press). The estimated effects of service learning on students' intercultural effectiveness. Journal of College Student Development.

King, P. M., Kendall Brown, M., Lindsay, N. K., \& VanHecke, J. R. (2007). Liberal arts student learning outcomes: An integrated approach. About Campus, 12(4), 2-9.

Kuh, G. D. (2008). High-impact educational practices: What they are, who has access to them, and why they matter. Washington, DC: Association of American Colleges and Universities.

Kuh, G. D., Kinzie, J., Schuh, J. H., Whitt, E. J. \& Associates. (2010). Student success in college: Creating conditions that matter. San Francisco, CA: Jossey-Bass.

Martin, G. L., Hevel, M. S., Asel, A. M., \& Pascarella, E. T. (2011). New evidence on the effects of fraternity and sorority affiliation during the first year of college. Journal of College Student Development, 52(5), 543-559.

National Task Force on Civic Learning and Democratic Engagement. (2012). A crucible moment: College learning and democracy's future. Washington, DC: Association of American Colleges and Universities.

O'Neill, N. (2012). Promising practices for personal and social responsibility: Findings from a national research collaborative. Washington, DC: Association of American Colleges and Universities.

Pascarella, E., Edison, M., Nora, A., Hagedorn, L., \& Terenzini, P. (1996). Influences on students' openness to diversity and challenge in the first year of college. Journal of Higher Education, 67, 174-195.

Pascarella, E. T., \& Terenzini, P. T. (2005). How college affects students: A third decade of research. San Francisco, CA: Jossey-Bass.

Rest, J., Narvaez, D., Thoma, S., \& Bebeau, M. (1999). DIT2: Devising and testing a revised instrument of moral judgment. Journal of Educational Psychology, 91, 644-659.

Ryff, C. (1989). Happiness is everything, or is it? Explorations on the meaning of psychological well-being. Journal of Personality and Social Psychology, 57, 1069-1081.

Ryff, C., \& Keyes, C. (1995). The structure of psychological well-being revisited. Journal of Personality and Social Psychology, 69, 719-727.

Simons, L., \& Cleary, B. (2006). The influence of service learning on students' personal and social development. College Teaching, 54(4), 307-319.

Stevens, J. P. (2002). Applied multivariate statistics for the social sciences (4th ed.). Hillsdale, NJ: Erlbaum.

Vogelgesang, L. J., \& Astin, A. W. (2000). Comparing the effects of community service and servicelearning. Michigan Journal of Community Service Learning, 7(1), 25-34.

Zlotkowski, E. (Ed.) (2002). Service-learning and the first-year experience: Preparing students for personal success and civic responsibility (Monograph No. 34). Columbia, SC: University of South Carolina, National Resource Center for the First-Year Experience and Students in Transition. 